\title{
The role of TGF- $\beta$ or BMPR2 signaling pathway-related miRNA in pulmonary arterial hypertension and systemic sclerosis
}

\author{
Bei Xu, Guanhua Xu, Ye Yu and Jin Lin*
}

\begin{abstract}
Pulmonary arterial hypertension (PAH) is a severe complication of connective tissue disease (CTD), causing death in systemic sclerosis (SSc). The past decade has yielded many scientific insights into microRNA (miRNAs) in PAH and SSc. This growth of knowledge has well-illustrated the complexity of microRNA (miRNA)-based regulation of gene expression in PAH. However, few miRNA-related SSC-PAH were elucidated. This review firstly discusses the role of transforming growth factor-beta (TGF- $\beta$ ) signaling and bone morphogenetic protein receptor type II (BMPR2) in PAH and SSC. Secondly, the miRNAs relating to TGF- $\beta$ and BMPR2 signaling pathways in PAH and SSc or merely PAH were subsequently summarized. Finally, future studies might develop early diagnostic biomarkers and target-oriented therapeutic strategies for SSc-PAH and PAH treatment.
\end{abstract}

Keywords: Pulmonary arterial hypertension, miRNAs, Systemic sclerosis

\section{Introduction}

Systemic sclerosis (SSc) is a complex, multisystem disease characterized by fibrosis and excessive collagen deposition within the skin and internal organs, chronic inflammation, autoimmune dysregulation, and microvascular endothelial dysfunction [1]. With the advent of angiotensin-converting enzyme inhibitors to treat the SSc renal crisis, SSc-associated pulmonary arterial hypertension (SSc-PAH) has emerged as a leading cause of morbidity and mortality of premature deaths. Therefore, SSc-PAH has a poor prognosis [2-9]. PAH is the leading cause of death in SSc and affects up to $12 \%$ of all patients with SSc, with a $50 \%$ mortality rate within 3 years of PAH diagnosis [10]. Annual mortality of PAH remains high at up to $10 \%$ in idiopathic PAH [11-14]. PAH is defined by an elevated mean pulmonary artery pressure (mPAP) of > $25 \mathrm{mmHg}$, with a pulmonary capillary wedge pressure of

*Correspondence: linjinzju@zju.edu.cn

Department of Rheumatology, The First Affiliated Hospital, Zhejiang University School of Medicine, \#79 Qingchun Road, Hangzhou, Zhejiang Province, People's Republic of China 310003
$<15 \mathrm{mmHg}$. The prevalence of SSc-PAH among patients with SSc varies but is between 10 and 12\% [10].

SSc-PAH occurs as a consequence of progressive remodeling of the small- to medium-sized pulmonary vasculature. The exact mechanisms of disease progression are still unclear, but it is believed that inflammation and endothelial injury are common precursors $[15,16]$. In addition, pulmonary artery vasoconstriction and cellular proliferation occur during PAH progression. Further ischemia-reperfusion injury in the pulmonary vasculature promotes additional cytokine release, furthering vascular remodeling, fibrosis, and intraluminal microthrombosis. The end outcome is a progressive increase in pulmonary vascular resistance, pulmonary arterial pressure, and right ventricular (RV) pressure overload [17].

Generally, the PAH is thought to be characterized by a disbalance in transforming growth factor-beta (TGF$\beta)$ and bone morphogenetic protein (BMP) signaling [18]. Bone morphogenetic protein receptor type II (BMPR2) is known to be involved in osteogenesis and cell differentiation. The BMPR2 pathway inhibits SMC original author(s) and the source, provide a link to the Creative Commons licence, and indicate if changes were made. The images or other third party material in this article are included in the article's Creative Commons licence, unless indicated otherwise in a credit line to the material. If material is not included in the article's Creative Commons licence and your intended use is not permitted by statutory regulation or exceeds the permitted use, you will need to obtain permission directly from the copyright holder. To view a copy of this licence, visit http://creativecommons.org/licenses/by/4.0/. The Creative Commons Public Domain Dedication waiver (http://creativeco mmons.org/publicdomain/zero/1.0/) applies to the data made available in this article, unless otherwise stated in a credit line to the data. 
cell proliferation within the pulmonary circulation, primarily within the small pulmonary arterioles. When mutated, BMPR2 is associated with an increased susceptibility to develop PAH [19]. TGF- $\beta$ signaling pathways have a complex and opposing effect on tissues [18]. TGF- $\beta$ superfamily ligands modulate a wide range of developmental programs, cellular processes, and disease states. TGF- $\beta 1$ has vital physiological roles in embryonic development, angiogenesis, wound healing, inflammation, and immune cell function by $\mathrm{T}$ cell regulation and differentiation. However, excessive TGF- $\beta 1$ production is associated with fibrotic lung diseases [20]. Dysregulated TGF- $\beta$ signaling potentially causes inflammation, autoimmune disorders, fibrosis, cancer, or PAH [21].

The mortality and therapeutic response in SSc-PAH are worse than idiopathic pulmonary arterial hypertension (IPAH) and might partially be due to its multifaceted underlying mechanisms and the multisystem nature [16]. Therefore, a multidisciplinary approach composing an earlier diagnosis or therapy with biomarkers and better characterization of the clinical phenotypes of SSc-PAH could be helpful in SSc-PAH management. In addition, more understanding of the potential biomarkers involved with PAH and SSc, such as microRNA (miRNAs), might benefit for predicting the presence and progression and identify the therapeutic target of PAH and SSc-PAH.
miRNAs represent 21 to 25 nucleotide non-coding small RNAs that negatively regulate gene expression at the post transcription level. Thus, miRNAs are regulatory molecules addressed as potential biomarkers and therapeutic targets in rheumatic diseases. However, previous studies found and discussed few miRNAs related to transforming growth factor-beta (TGF- $ß$ ) and Bone Morphogenetic Protein Receptor Type II (BMPR2) signaling in SSC-PAH. This study reviews the miRNAs relating to these two signaling in PAH and/or SSc from previous literature and further investigates their pathological and regulatory roles in SSc-PAH.

\section{Narrative review process}

Twenty-one candidate miRNAs were obtained firstly by the first search in PubMed (https://pubmed.ncbi.nlm. nih.gov/) and Cochrane Library (https://www.cochraneli brary.com/) using the keywords of miRNA, PAH, SSc, TGF- $\beta$, and BMPR2 (Fig. 1). The 31 literature related to these miRNAs were obtained by the second search in PubMed and listed in Table 1.

\section{The role of TGF- $\beta$ signaling in PAH}

TGF- $\beta$ signaling has been strongly implicated in the pathogenesis of PAH. The activation of the TGF- $\beta$ signal is vital for the formation of PAH [50]. TGF- $\beta$ signaling regulates several processes, including cellular

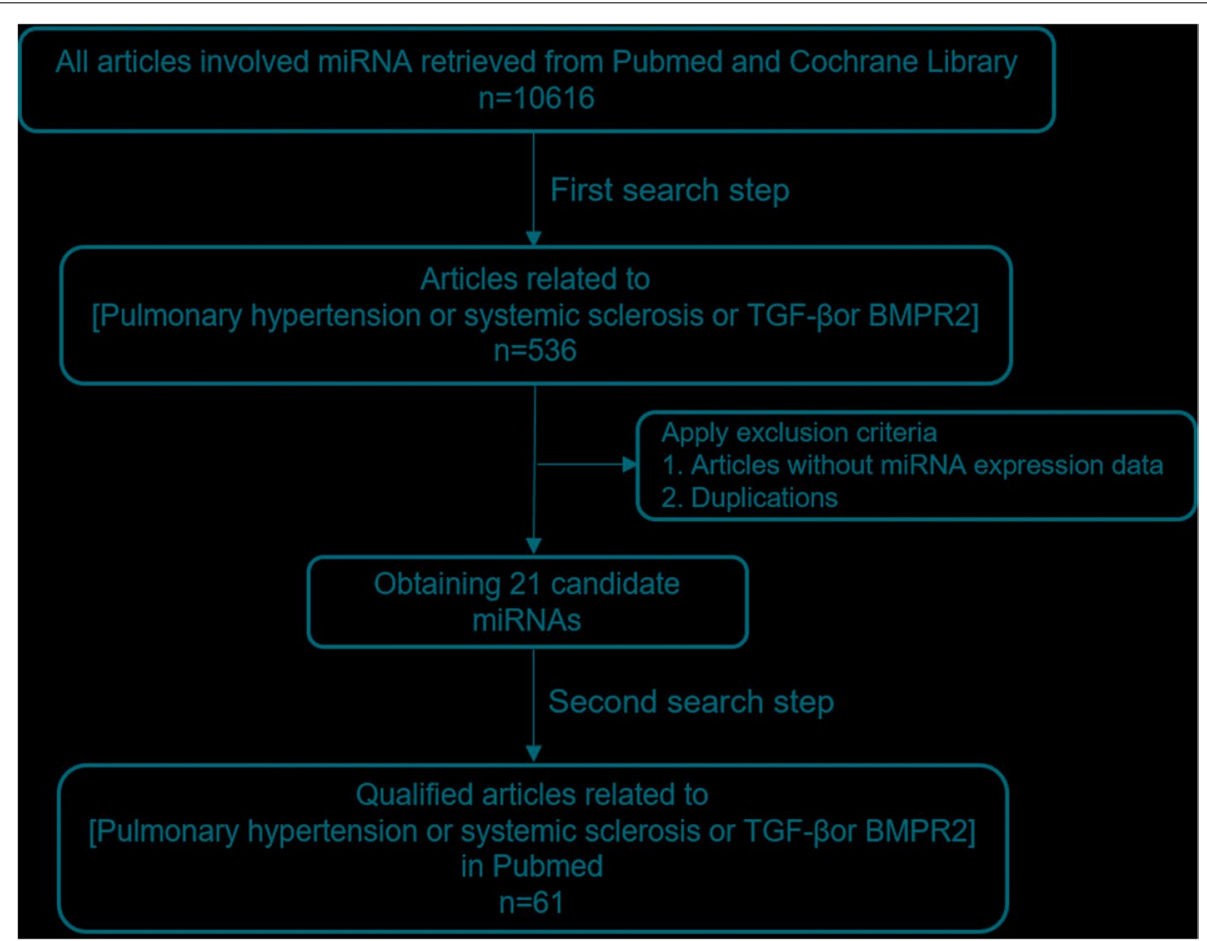

Fig. 1 Flowchart of searching candidate miRNAs and related articles included in this study 
Table 1 A List of microRNAs in this study

\begin{tabular}{|c|c|c|c|c|}
\hline miRNA & Experimental system & Targets & Function & References \\
\hline \multicolumn{5}{|c|}{ Putative miRNAs related to PAH and SSC } \\
\hline miR-21 & Human PAECs and PASMCs & KLF4, Smad-8 & $\begin{array}{l}\text { PASMC differentiation and inhibition } \\
\text { of PASMC proliferation }\end{array}$ & {$[22]$} \\
\hline miR-21 & $\begin{array}{l}\text { Human PAECs } \\
\text { Rodent model of PH }\end{array}$ & $\begin{array}{l}\text { BMPR2 } \\
\text { PDCD4/caspase-3 } \\
\text { Proliferating cell nuclear antigen } \\
\text { cyclin D1 } \\
\text { BCl-xL } \\
\text { DDAH1 }\end{array}$ & $\mathrm{PAH}$ & [23-26] \\
\hline miR-21 & Fibroblasts & SMAD7 & Skin fibrosis & {$[27]$} \\
\hline let-7g & Human patients with SSc-PH & multiple & $\mathrm{PAH}$ & {$[28]$} \\
\hline let-7a & Human or mouse skin fibroblasts & Type I collagen & Tissue fibrosis in the skin & [29] \\
\hline miR-155 & Skin of mice & $\begin{array}{l}\text { CK1a } \\
\text { SHIP-1 }\end{array}$ & Dermal fibrosis & {$[30]$} \\
\hline miR-29a & $\begin{array}{l}\text { Skin biopsy and fibroblast samples } \\
\text { from SSc patients and healthy controls } \\
\text { The mouse model of bleomycin- } \\
\text { induced skin fibrosis }\end{array}$ & Type I and type III collagen & Fibrogenesis of SSC & {$[31]$} \\
\hline miR-140-5p & Marrow stromal cells & TGF- $\beta R 1$ & $\begin{array}{l}\text { TGF- } \beta R 1 \text { regulation } \\
\text { Adipocyte differentiation }\end{array}$ & [32] \\
\hline \multicolumn{5}{|c|}{ miRNA related to TGF- $\beta$-signaling pathway } \\
\hline miR-155 & $\begin{array}{l}\text { Lung fibroblasts and PBMC from SSC- } \\
\text { ILD patients }\end{array}$ & Multiple & Dysregulated lung gene expression & [30] \\
\hline miR-145 & $\begin{array}{l}\text { Normal and cutaneous scleroderma } \\
\text { skin tissues } \\
\text { Human fibroblasts }\end{array}$ & SMAD7 SMAD3 COL1A1 & SSC & [33] \\
\hline miR-145 & $\begin{array}{l}\text { PAH patients } \\
\text { Human PASMCs } \\
\text { Hypoxia-induced PAH rats }\end{array}$ & $A B C A 1$ & PASMCs proliferation and migration & {$[32]$} \\
\hline miR-221-3p & $\begin{array}{l}\text { Human PASMC } \\
\text { PAH animal models }\end{array}$ & AXIN2 & PASMC proliferation & [34] \\
\hline miR-124 & $\begin{array}{l}\text { Pulmonary vascular and circulating } \\
\text { progenitor endothelial cells isolated } \\
\text { from patients }\end{array}$ & PTBP1 & $\begin{array}{l}\text { Metabolic and proliferative abnormali- } \\
\text { ties in PAH ECs }\end{array}$ & {$[35]$} \\
\hline miR-124 & $\begin{array}{l}\text { Human PASMCs } \\
\text { Nonfamilial human PAH } \\
\text { PAH mouse and rat models }\end{array}$ & $\begin{array}{l}\text { NFATC1 } \\
\text { CAMTA1 } \\
\text { PTBP1 } \\
\text { STAT3/NFAT signaling }\end{array}$ & $\begin{array}{l}\text { PASMC proliferation, prodifferentia- } \\
\text { tion, and survival } \\
\text { Inflammation } \\
\text { Pulmonary vascular remodeling }\end{array}$ & [36] \\
\hline miR-143 & $\begin{array}{l}\text { PAH patients } \\
\text { Human PASMCs } \\
\text { Hypoxia-induced PAH rats }\end{array}$ & $\mathrm{ABCA} 1$ & PASMC proliferation and migration & [32] \\
\hline miR-143-3p & $\begin{array}{l}\text { Calf models of PAH } \\
\text { PAH patients } \\
\text { Mice }\end{array}$ & Multiple & $\mathrm{PH}$ & [37] \\
\hline miR-181a-5p & $\begin{array}{l}\text { Human pulmonary artery endothelial } \\
\text { cells } \\
\text { PAH mice }\end{array}$ & Multiple & Vascular remodeling & [38] \\
\hline $\begin{array}{l}\text { miR-29 } \\
\text { miR-29b }\end{array}$ & $\begin{array}{l}\text { Mice } \\
\text { Mice pulmonary fibroblasts }\end{array}$ & $\begin{array}{l}\text { TGF- } \beta \\
\text { CTGF } \\
\text { SMAD3 }\end{array}$ & Pulmonary fibrosis & [39] \\
\hline miR-455-3p-1 & Normal and PAH patients & FGF7 & Inhibit the proliferation of PASMCs & {$[40]$} \\
\hline miR-223-3p & $\begin{array}{l}\text { PASMCs } \\
\text { Rat }\end{array}$ & ITGB3 & Pulmonary vascular remodeling & [41] \\
\hline miR-17/92 family & $\begin{array}{l}\text { HEK293 } \\
\text { Rodent } \\
\text { model of PH }\end{array}$ & $\begin{array}{l}\text { BMPR2 } \\
\text { STAT3 }\end{array}$ & Development of PH & [42] \\
\hline
\end{tabular}


Table 1 (continued)

\begin{tabular}{|c|c|c|c|c|}
\hline miRNA & Experimental system & Targets & Function & References \\
\hline \multicolumn{5}{|c|}{ miRNA related to BMPR2 signaling pathway } \\
\hline miR-204 & $\begin{array}{l}\text { PASMCs in both human and rodent } \\
\text { PAH }\end{array}$ & $\begin{array}{l}\text { SHP2 } \\
\text { NFAT }\end{array}$ & $\begin{array}{l}\text { PAH-PASMC proliferation and resist- } \\
\text { ance to apoptosis }\end{array}$ & [43] \\
\hline miR-130/301 family & $\begin{array}{l}\text { Pulmonary vessels and plasma from } \\
\text { mammalian models and PH patients } \\
\text { PAECs and PASMCs in mice model }\end{array}$ & PPARY & Cell proliferation in $\mathrm{PH}$ & {$[44]$} \\
\hline miR-130/301 family & $\begin{array}{l}\text { Human PASMCs and PAECs } \\
\text { Mice blood and lung tissue }\end{array}$ & PPARY & Cell proliferation in $\mathrm{PH}$ & {$[45]$} \\
\hline miR-130/301 family & Human PAECs & $\begin{array}{l}\text { PPARY } \\
\text { LRP8 }\end{array}$ & $\begin{array}{l}\text { Pulmonary vascular stiffening } \\
\text { Extracellular matrix remodeling }\end{array}$ & {$[46]$} \\
\hline miR-424 (322) & $\begin{array}{l}\text { The blood of PAH patients } \\
\text { Hypoxia-induced PAECs } \\
\text { Monocrotaline rat model of PH }\end{array}$ & SMURF1 & Afterload of the right ventricle & {$[47]$} \\
\hline miR-17/92 family & Human PASMCs & PDLIM5 & $\begin{array}{l}\text { PASMC proliferation and differentia- } \\
\text { tion }\end{array}$ & [48] \\
\hline miR-20a & $\begin{array}{l}\text { Mice } \\
\text { Human PASMCs }\end{array}$ & BMPR2 & $\begin{array}{l}\text { Prevent pulmonary arterial vascular } \\
\text { remodeling }\end{array}$ & [49] \\
\hline
\end{tabular}

PAH pulmonary arterial hypertension, SSC systemic sclerosis, PAEC pulmonary artery endothelial cell, PASMC pulmonary artery smooth muscle cell, KLF4 Kruppel Like Factor 4, Smad-8 Mothers against decapentaplegic homolog 8, PH pulmonary hypertension, BMPR2 Bone Morphogenetic Protein Receptor Type II, PDCD4 Programmed Cell Death 4, BCl-xL B cell lymphoma-extra large, DDAH1 dimethylarginine dimethylaminohydrolases 1, SMAD7 Mothers against decapentaplegic homolog 7, CK1a casein kinase 1a, SHIP-1 Src homology 2-containing inositol phosphatase-1, TGF- $\beta R 1$ transforming growth factor-beta receptor type 1, SSC-ILD systemic sclerosis associated interstitial lung disease, SMAD7 Mothers against decapentaplegic homolog 7, SMAD3 Mothers against decapentaplegic homolog 3 , COL1A1 Collagen Type I Alpha 1 Chain, ABCA1 ATP-binding cassette transporter A1, AXIN2 Axis inhibition protein 2, PTBP1 polypyrimidine tract-binding protein 1, NFATC1 nuclear factor of activated T cells 1, CAMTA1 calmodulin-binding transcription activator 1, STAT3 signal transducer and activator of transcription 3, NFAT nuclear factor of activated T cells, TGF- $\beta$ Transforming growth factor-beta, CTGF connective tissue growth factor, FGF7 Fibroblast Growth Factor 7, ITGB3 Integrin alpha-V/ beta-3, SHP2 Src homology region 2 domain-containing phosphatase-2, PPARY Peroxisome proliferator- activated receptor gamma, LRP8 lipoprotein receptor-related protein 8, SMURF1 SMAD-specific E3 ubiquitin protein ligase 1, PDLIM5 PDZ And LIM Domain 5

proliferation and angiogenesis (Fig. 2). TGF- $\beta$ is elevated in PAH and implicated in its pathogenesis based on clinical and experimental data [51, 52]. TGF-ß serum concentrations are raised in IPAH patients [18]. The antiproliferative BMP signaling is decreased in the PAH lung, while elevated levels of circulating TGF- $\beta$ enhance the proliferation of vascular cells leading to occlusive remodeling in the pulmonary vasculature [53]. A study of monocrotaline (MCT)-treated rat model demonstrated that inhibiting the TGF- $\beta$ pathway with orally active small-molecule transforming growth factor-beta receptor type 1 (TGF- $\beta R 1$ ) inhibitor can reduce MCTinduced pulmonary hypertension (MCT-PH) [54]. These findings confirmed that endothelial apoptosis induces pulmonary artery smooth muscle cell (PASMC) growth via TGF- $\beta$. Adenovirus-mediated overexpression of TGF- $\beta$ R1 causes pulmonary fibrosis and PH associated with increased TGF- $\beta$ signaling in the lung tissue surrounding the remodeled pulmonary blood vessels. TGF- $\beta$ binding to its receptor activates downstream signaling cascades, such as SMAD proteins. Vascular remodeling in PAH results from smooth muscle cell hypertrophy and proliferation of vascular cells. Increased signaling via TGF- $\beta$ and its downstream mediators SMAD2/3 has been proposed to drive lung vascular remodeling [55]. A previous study showed that PAH rats injected with
TGF- $\beta 1$ recombinant protein could activate the mRNA and protein expression of RhoA and ROCK, revealing that overexpression of TGF- $\beta 1$ might activate the RhoA/ ROCK signaling pathway and promote the occurrence and development of PAH (Fig. 2) [56].

\section{The role of BMPR2 in PAH}

BMPR2 is a transmembrane serine/threonine kinase receptor of the BMP pathway, essential for embryogenesis, development, and adult tissue homeostasis. BMPinduced heteromeric complex formation of BMPR2 with BMP type I receptor (BMPR1). BMPR2 subsequently activates BMPR1 by phosphorylation. After that, the activated BMPR1 propagates the signal into the cell through phosphorylation of the SMAD1/5/8 transcription factors (Fig. 3) [57].

A previous study revealed reduced BMPR2 protein in patients with SSc-PAH, and an increased proteasomal degradation of BMPR2 was found in a relevant mouse model [58]. Collectively, these results suggest that TGF- $\beta$ might impair the BMP signaling through the degradation of its receptor and promote the PAH susceptibility in SSc, which might provide a unifying mechanism across different forms of PAH [58]. Although the BMPR2 pathway is essential for vascular homeostasis and there is a strong correlation between BMPR2 mutations and PAH, the 


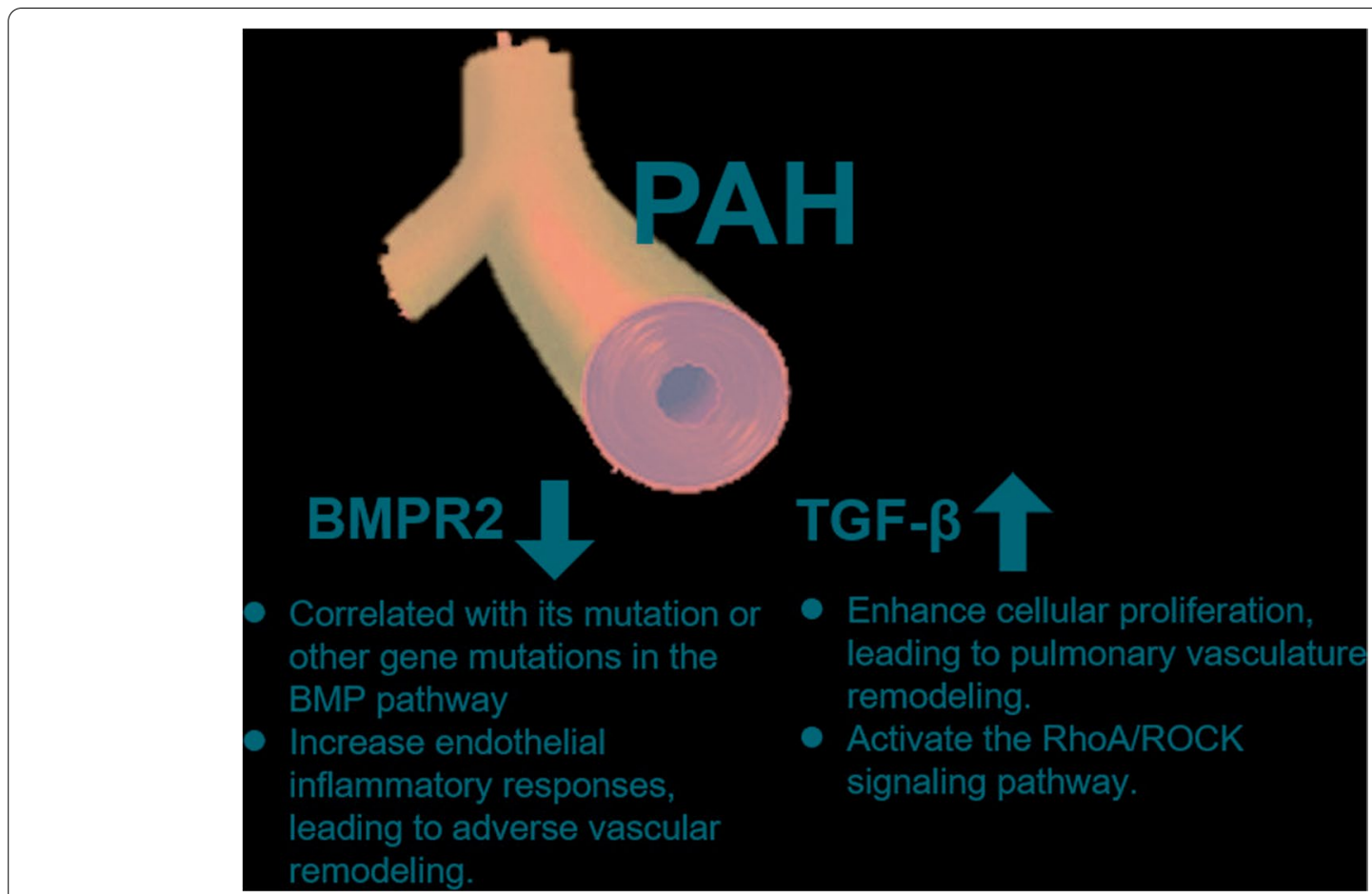

Fig. 2 The role of TGF and BMPR2 signaling in PAH. Abbreviation: TGF, transforming growth factor; BMPR2, Bone Morphogenetic Protein Receptor Type II; PAH, pulmonary arterial hypertension

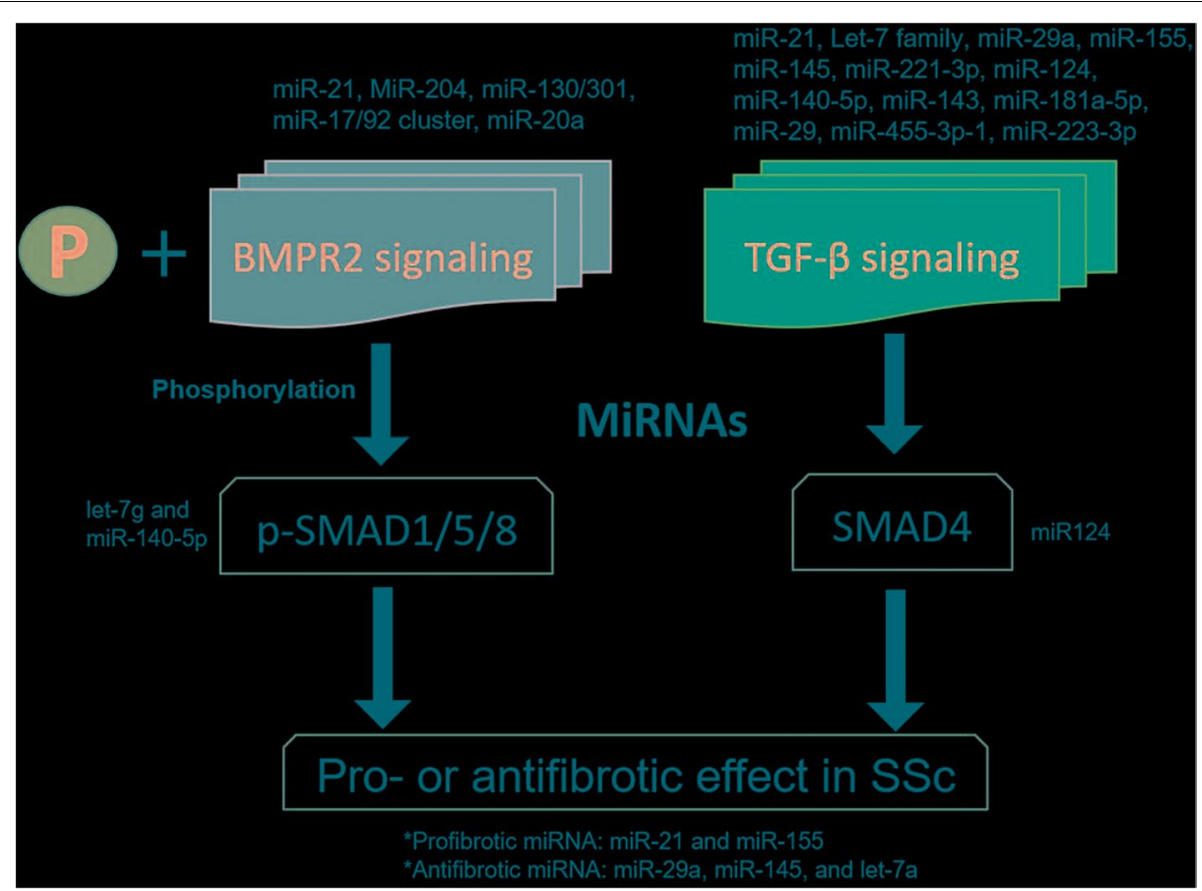

Fig. 3 The SSc-related miRNAs in TGF- $\beta$ signaling and BMPR2 signaling. Abbreviation: TGF- $\beta$, Transforming growth factor-beta; BMPR2, SSC, systemic sclerosis; SMAD1/5/8, Mothers against decapentaplegic homolog 1/5/8; SMAD4 Mothers against decapentaplegic homolog 4 
incomplete penetrance of BMPR2 mutations (20-30\%) suggests other genetic and environmental factors might contribute to this disease [59]. One BMPR2 splice variant lacks exon 12, which is the largest exon of the gene and encodes the cytoplasmic tail. It has been shown that carriers of this variant are more prone to develop PAH [60]. Furthermore, mutations in other genes in the BMP pathway further strengthen the notion of a causal role for this pathway in PAH (Fig. 2) [61]. Moreover, the coexistence of modifier genes, infections, toxic exposure, inflammation, or alterations in estrogen metabolism has been described [61-64], and some of them were found to downregulate BMPR2 expression. For example, proinflammatory cytokines such as tumor necrosis factor $\alpha$ (TNF- $\alpha$ ) and interleukin 6 (IL-6) induce miRNA expression that inhibits BMPR2 expression [42]. Furthermore, BMPR2 is essential for maintaining the pulmonary artery endothelial cell lining barrier function, and BMPR2 deficiency increases endothelial inflammatory responses, thereby contributing to adverse vascular remodeling (Fig. 2) [65-67]. Recent study showed BMPR2 expression and downstream signaling is reduced in the lung vasculature of patients with idiopathic and hereditary PAH [68]. Despite increased BMPR2 expression in the lung vasculature, the MCT and SuHx rat models did develop PAH and impaired downstream BMPR2-Smad signaling [68].

TGF- $\beta$ and BMPR2 signaling pathway-related miRNA in PAH and SSC

Recently, much attention has been paid to miRNAs as a potential biomarker for PAH [28, 69]. Several clinical factors and biomarkers have been implicated in
SSc-associated PAH $[48,70,71]$. In recent reports, miRNAs were proposed as possible novel players in SSc fibrosis, capable of modulating several fibrotic-related genes (Fig. 3) [72]. The aberrant expression of pro-fibrotic and anti-fibrotic miRNAs in SSc might play critical roles in the disease (Fig. 3) [73]. miRNA has initially been thought to function only intracellularly, but recent data suggest that it is also secreted and detected in the circulation [74]. Various miRNAs have been identified to be involved in the pathogenesis of PAH [75]. Some circulating miRNAs were dysregulated in pulmonary hypertensive $(\mathrm{PH})$ and vary according to the severity of $\mathrm{PH}$ human [76]. In this review, the miRNAs involved in PAH and SSc were searched in the PubMed and Cochrane Library database, and 21 candidate miRNAs that involved TGF- $\beta$ and/or BMPR2 signaling pathway were reported (Table 1). These miRNAs were classified by (I) Putative miRNAs related to both PAH and SSc, (II) miRNA related to TGF-b signaling pathway in PAH, and (III) miRNA related to BMPR2 signaling pathway in $\mathrm{PAH}$ and described individually for each miRNA.

\section{Putative miRNAs related to both PAH and SSC}

The miRNAs more evidently related to SSc-PAH are listed in Table 2, classified by apoptosis, cell proliferation, angiogenesis, cell differentiation, cell migration, vasodilation, pulmonary fibrosis, pulmonary hypertension, and pulmonary vascular remodeling. Those miRNAs were found to regulate TGF- $\beta$ signaling pathway or BMPR2 signaling pathway. Each of these miRNAs is discussed separately by paragraph.

Table 2 Pathological mechanisms and putative miRNA in SSC-PAH

\begin{tabular}{|c|c|c|c|}
\hline Mechanism & Putative miRNA & Potential function & Reference \\
\hline \multirow[t]{2}{*}{ Apoptosis } & $\operatorname{miR}-21$ & Reduce the pulmonary endothelial cell apoptosis & [22] \\
\hline & miR-140-5p & Promote cell apoptosis & [31] \\
\hline \multirow[t]{2}{*}{ Cell proliferation } & miR-21 & Antiproliferative effect in PAEC and PASMC & [74] \\
\hline & miR-140-5p & Inhibit cell proliferation & {$[31,77,78]$} \\
\hline Angiogenesis & $\operatorname{miR}-21$ & Decrease angiogenesis & [75] \\
\hline Cell differentiation & miR-140-5p & Promote cell differentiation & [31] \\
\hline Cell migration & miR-140-5p & Inhibit cell migration & {$[77,78]$} \\
\hline Vasodilation & miR-21 & Increase the pulmonary vasodilation & [75] \\
\hline \multirow[t]{3}{*}{ Pulmonary fibrosis } & miR-21 & Target of fibrosis inhibition & [26] \\
\hline & let-7 family & Reduce fibrosis & [79] \\
\hline & miR-155 & Reduce fibrosis & {$[32,80,81]$} \\
\hline Pulmonary hypertension & miR-21 & Increase the lung DDAH1 and cGMP levels and attenuate pulmonary hypertension & [76] \\
\hline Pulmonary vascular remodeling & miR-29a & $\begin{array}{l}\text { Decrease pulmonary artery pressure and right ventricle hypertrophy index and } \\
\text { ameliorate pulmonary vascular remodeling }\end{array}$ & {$[29,82,83]$} \\
\hline
\end{tabular}


miR-21 Several previous studies presented that microRNA-21 (miR-21) might play a central regulatory role for $\mathrm{PH}$ and heritable pulmonary arterial hypertension (HPAH) patients [22, 23]. miR-21 could be a critical component of BMP-induced growth suppression of vascular cell proliferation in HPAH 74 and regulate some target genes for attenuating $\mathrm{PH}$ such as BMP receptor type 2, programmed cell death 4 (PDCD4)/caspase-3, proliferating cell nuclear antigen, cyclin D1, B cell lymphomaextra large (Bcl-xL), and dimethylarginine dimethylaminohydrolases 1 (DDAH1) [23-26]. Besides, in terms of TGF- $\beta$ signaling, miR-21 was revealed to suppress baseline expression of the anti-fibrotic signaling molecule SMAD7, thereby promoting pro-fibrotic activity in spinal fibroblasts [27]. It also exerts a pro-fibrotic effect via Smad7 in SSc dermal fibroblasts [33, 79]. Thus, MiR-21 could be induced by TGF- $\beta$ and, in turn, downregulates Smad7, which promotes the pro-fibrotic signal of TGF$\beta$. Therefore, miR-21 might be an enhancer that amplifies the effect of TGF- $\beta$ in SSc fibrosis, and it might be the therapeutic target of SSc-PAH.

Let-7 family Let-7 family miRNAs are thought to be potential biomarkers for the presence and severity of PAH patients with SSc. The expression level of let-7 family microRNAs in skin and lung tissue was lower in SSc patients with $\mathrm{PH}$ than those without $\mathrm{PH}$. Let-7b and Let-7d expression levels negatively correlated with the severity of $\mathrm{PH}$ in patients with SSc. Let-7e expressed in the lungs of patients with SSc related to TGF- $\beta$ signal pathway $[22,28,82]$. In the mouse model of bleomycin-induced dermal sclerosis, let-7a expression was downregulated in SSc and localized scleroderma (LSc) skin both in vivo and in vitro, compared with normal or keloid skin. Serum let-7a concentration was significantly decreased in these patients, especially in localized scleroderma patients. Moreover, miRNA injection can improve the skin fibrosis induced by bleomycin in mice. Thus, let-7a-mediated regulation of collagen expression may lead to new therapeutic approaches against SSc and LSc [29].

miR-29a The first report of miRNAs involved in SSc pathogenesis was published by Kawashita et al., showing that miR-29a was detectable in serum and might be reduced in patients with SSc, which was assumed to be relevant an actor for developing SSc in the early disease stage [83]. Although miR-29a targets Collagen Type I Alpha 1 Chain (COL1A1), the significant differences in serum levels of miR-29a between controls and SSc patients were not observed [31]. However, lower miR-29a levels were associated with higher right ventricular systolic pressure in SSc patients, suggesting the involvement of this miRNA in PH's pathogenesis. Furthermore, a decrease of miR-29a-3p expression was found either in pulmonary adventitial fibroblasts with hypoxia induction or cultured pulmonary adventitial fibroblasts with knockdown hypoxia-inducible factor-1 $\alpha$ or Smad3. Furthermore, miR-29a-3p can significantly decrease pulmonary artery pressure and right ventricle hypertrophy index, ameliorate pulmonary vascular remodeling in hypoxic pulmonary hypertension rats, and suggest regulating pulmonary adventitial fibroblasts hypoxia and preventative and therapeutic potential in hypoxic $\mathrm{PH}$ [77]. In mice with overexpression of miR-29a, the TGF- $\beta$ expression and phosphorylated SMAD2/3 decreased with the downregulation of collagen I and III [84]. These results can suggest that intervention ofmiR-29a may be a therapeutic strategy for attenuating SSc-PAH.

miR-155 MircroRNA-155 (miR-155) might play a role in the progression of lung fibrosis in SSc [85]. Increased expression of miR-155 in patients with SSc-systemic sclerosis-associated interstitial lung disease (SSc-ILD) is associated with impaired respiratory function and increased lung fibrosis [85]. miR-155 was found to directly target SMAD2 mRNA by the decreased expressions of SMAD2 [78]. Overexpression of miR-155-5p inhibited the TGF- $\beta 1 / \mathrm{Smad} 2 / 3$ signaling pathway, as evidenced by decreased protein expression of TGF- $\beta 1$, pSmad-2, and pSmad-3 in rat vascular smooth muscle cells [80]. Although miRNA expression is tissue-specific and cell-type-dependent, the circulating fraction of miR155 may act as a biomarker for SSc [78]. Since miR-155 might act as a regulator of the TGF- $\beta 1 / \mathrm{Smad} 2 / 3$ signaling pathway, it may also be a potential therapeutic target for SSc-PAH.

miR-145 Downregulation of miR-145 was observed in SSc fibroblasts, while its predicted target Smad3 was upregulated [33]. Thus, MiR-145 may regulate TGF- $\beta$ signaling through Smad3; however, more mechanistic studies need to confirm this link. A previous study for PAH patients, PASMCs, and hypoxia-induced PAH rats showed that miR-145 could promote hypoxia-induced proliferation and migration of PASMCs by regulating ATP-binding cassette expression subfamily A member 1(ABCA1), which suggested that miR-145 might involve in the pathogenesis of PAH [32]. Another previous report showed that the expression levels of miR-145 and its target proteins such as myocardin, smooth muscle myosin heavy chain were significantly higher in human PAH with concentric lesions than in plexiform ones [81]. Since miR-145 was found to associate with both SSc and $\mathrm{PAH}$, it may also be a potential therapeutic target for SSc-PAH. 


\section{miRNA related to TGF- $\beta$ signaling pathway in PAH}

miR-140-5p Recent studies have demonstrated a downregulation of microRNA-140-5p (miR-140-5p) levels in treatment-naive patients and experimental models of PAH. In contrast, miR-140-5p could inhibit proliferation and differentiation of HPASMCs and promotes apoptosis in hypoxia, prevent the development of $\mathrm{PAH}$, and attenuated the progression of established PAH [30, 86]. The potential targets of its regulation included DNA methyltransferase 1 (Dnmt1), which can downregulate superoxide dismutase 2 (SOD2) expression, and SMAD-specific E3 ubiquitin protein ligase 1 (SMURF1), which can alter BMP signaling $[30,86]$. Besides, the primary target genes of miR-140-5p were mainly located in Notch, TGF-b, PI3K/Akt, and Hippo signaling pathways [87]. TGF- $\beta R 1$ was found to be one of the direct targets of miR-140-5p. Supplementing miR-140-5p in ST2 bone marrow stromal cells reduced the level of TGF- $\beta R 1$, while suppression of endogenous miR-140-5p increased TGF- $\beta R 1$ [88]. In summary, miR-140-5p is an essential regulator in $\mathrm{PAH}$ pathology and may serve as a therapeutic target for $\mathrm{PAH}$ [34].

miR-221-3p A previous study revealed that elevated expression of MicroRNA-221-3p (miR-221-3p) was observed in lung tissue and PASMC of PAH patients and animal models of PAH and miR-221-3p together with axis inhibition protein 2 (AXIN2) might regulate the proliferation of PASMC [89]. In rat cardiac fibroblasts, inhibition of miRNA-221/222 derepressed TGF- $\beta$-mediated pro-fibrotic mothers against decapentaplegic homolog 2 (SMAD2) signaling and downstream gene expression, whereas overexpression of both miRNAs blunted TGF$\beta$-induced pro-fibrotic signaling. The miRNA-221/222 family may target several genes involved in TGF- $\beta$ signaling, including c-Jun $\mathrm{N}$-terminal kinase 1 (JNK1), TGF- $\beta$ receptor 1 and TGF- $\beta$ receptor 2 , and ETS proto-oncogene 1 (ETS-1) [90]. Therefore, miRNA-221 might be involved in PAH pathology via TGF- $\beta$ signaling pathway and tumor suppressor Axin2.

miR-124 MicroRNA-124 (miR-124) is considered to regulate the TGF- $\beta$ signal in human according to previous studies [91]. TGF- $\beta$ activation can inhibit the expression of miR-124 and promote the expression of downstream Smad4 [35]. The reduced expression of miR-124 was observed in pulmonary vascular and circulating progenitor endothelial cells isolated from PAH patients, leading to the identification of miR-124 as a significant regulator of enhanced endothelial cell glycolysis in $\mathrm{PAH}$ via polypyrimidine tract-binding protein (PTBP1) and Pyruvate Kinase M2 (PKM2). Therefore, miR-124 or its targets might be developed for the treatment of PAH [36]. miR-124 could robustly inhibit the nuclear factor of activated T cells (NFAT) reporter activity and decrease both the dephosphorylation and the nuclear translocation of NFAT. It could also inhibit the NFAT-dependent transcription of IL-2 in Jurkat T cells. Furthermore, the overexpression of miR-124 inhibited human PASMC proliferation and maintained its differentiated phenotype by repressing the NFAT pathway. These results imply a potential value for miR-124 in the treatment of PAH [92].

miR-143 MicroRNA-143 (miR-143) is considered to regulate the TGF- $\beta$ signal in human according to previous studies [93]. It controls the proliferation of tracheal smooth muscle cells induced by TGF- $\beta 1$ through the activation of $\mathrm{T}$ cell nuclear factors (Fig. 2) [37]. A previous study showed the protective role of miR-143 in experimental $\mathrm{PH}$ in vivo and which could modulate smooth muscle and endothelial cell crosstalk in pulmonary vascular cells, whereas inhibition of miR-143-3p blocked experimental $\mathrm{PH}$. These findings confirm an essential role for the miR-143 in PAH pathobiology [94].

miR-181a-5p The bioinformatics analysis in previous report suggested that miR-181a negatively regulated TGF- $\beta$ R2. Overexpression of miR-181a and the downregulation of TGF- $\beta$ R2 promoted the migration and proliferation of gastric cancer cells [95]. miR-181a-5p overexpression directly suppressed early growth response factor 1 (Egr1), resulting in a downregulated TGF- $\beta 1 / \mathrm{Smad}$ pathway in hepatocellular carcinoma cells [96]. The missense mutation p.H288Y of Krüppel-like Factor 2 (KLF2) in pre-clinical $\mathrm{PAH}$, idiopathic $\mathrm{PAH}$, and heritable $\mathrm{PAH}$ were indicated to reduce the expressions of MicroRNA-181a-5p (miR-181a-5p) and MicroRNA-324-5p (miR-324-5p), the exosomal miRNAs induced by KLF2. Moreover, miR-181a-5p and miR-324-5p could reduce proliferative and angiogenic responses in patient-derived cells and attenuates disease progression in $\mathrm{PAH}$ mice, showing the potential therapeutic role of KLF2-regulated exosomal miRNAs in PAH [38].

miR-455-3p-1 Enforced expression of miR-455-3p partially suppressed epithelial-to-mesenchymal transition induced by TGF- $\beta$ both in breast cancer cells and tumor xenografts by directly inhibiting key components of TGF- $\beta$ signaling [40]. This observation suggested that miR-455-3p was one of the regulators of the TGF- $\beta$ signaling pathway. In a previous report, the differential expression of genes between the tissue of normal and PAH patients was analyzed by a microarray assay. The results suggested that microRNA-455-3p-1 (miR-455-3p-1) was downregulated in PAH patients. 
MiR-455-3p-1 upregulation was associated with reduced mRNA and protein levels of core RAS/ERK signal genes, suggesting that miR-455-3p-1 might involve the inhibition of the RAS/ERK pathway. In addition, upregulation of miR-455-3p-1 could inhibit the proliferation of PASMCs and alleviate PAH in vivo [97].

miR-223-3p The association between microRNA223-3p (miR-223-3p) and TGF- $\beta$ signaling pathway had been studied. Bioinformatics predicted that miR223-3p bound directly to the IncRNA ADAMTS9-AS2 and TGFBR3. ADAMTS9-AS2 transfection increased TGFBR3 mRNA and protein expressions in lung cancer cells, but miR-223-3p transfection significantly suppressed TGFBR3 expression. MiR-223-3p promotes proliferation, migration, and invasion of lung cancer cells by targeting TGFBR3 [41]. A recent report showed that the PAH pathological features in rats was alleviated as miR-223-3p overexpression and integrin subunit beta 3 (ITGB3) knockdown. It might reveal the role of miR223-3p in PAH via ITGB3 in the extracellular matrix (ECM) pathway [98]. The direct evidence is required to demonstrate whether miR-223-3p can alleviate PAH via TGF- $\beta$ signaling pathway.

\section{miRNA related to BMPR2 signaling pathway in PAH}

miR-29 The elevation of the miR-29 family was found to be associated with energy metabolism among HPAH patients. Metabolite 16 $\alpha$-hydroxyestrone (16 $\alpha \mathrm{OHE})$, one of the estrogens, can promote the development of HPAH through upregulation of miR-29; the improvement of HPAH in Bmpr2 mice after treated with anti-miR-29, revealing the potential of this miRNA as a therapeutic target of HPAH [39]. Since miR-29 was found to associate with both pulmonary fibrosis and HPAH, it may also be a potential therapeutic target for PAH.

miR-204 The inflammation and increased proliferation and survival of PASMCs have provided more understanding of PAH pathogenesis [43]. In addition, the increased activation of BMPR2-mediated signal transducer and activator of transcription 3 (STAT3) has been found in PASMC isolated from PAH patients [43]. Another report revealed that the disturbance of miR-204 expression played a key in the activation of STAT3/NFAT signaling, a signaling axis involved with PAH [99].

miR-130/301 family Heritable forms of $\mathrm{PH}$ have been defined as WHO group 1, consisting of individuals suffering from $\mathrm{PAH}$, stemming either from idiopathic and hereditary forms or secondarily from co-morbidities such as congenital heart disease, autoimmune disease, drug and toxin exposure, or infections [100]. Loss-offunction mutations in the BMPR2 gene account for over $80 \%$ of hereditary PAH cases and approximately $20 \%$ of idiopathic PAH cases [101].

A previous study reveals the role of miRNAs in the integrated control of $\mathrm{PH}$ pathogenesis, such as the proliferative and vasoconstrictive actions of the miR-130/301 family in $\mathrm{PH}[44,45]$. Besides, miR-130/301 modulated apelin-miR-424/503-FGF2 signaling in endothelial cells while modulated STAT3-miR-204 signaling in smooth muscle cells to promote $\mathrm{PH}$-associated phenotypes.

Pathogenic gene mutations from the TGF- $\beta /$ BMP signaling pathways have been identified and providing compelling evidence for a central role of dysregulated BMP signaling in PAH pathogenesis [102]. However, less is known about effectors and mechanisms that might regulate vascular stiffness by modulating ECM production/composition, and the molecular mechanisms controlling these processes are still under the research [46].

miR-424(322) A previous study showed that miR424(322) secreted by pulmonary arterial endothelial cells (PAECs) could target SMURF1 and sustain BMPR2 signaling [47]. Besides, an association between circulating miR-424(322) levels and the stage of right ventricle hypertrophy, as well as an inverse correlation between miR-424(322) and SMURF1 levels in the hypertrophied right ventricle, was found through the monocrotaline rat model of PH [47]. Therefore, due to its direct effect on heart function and correlation to sustaining BMPR2 signaling, miR-424(322) might has diagnostic value in PAH patients.

miR-17/92 cluster The expression of BMPR2 could be modulated by the miRNA cluster 17/92 (miR-17/92), and persistent activation of STAT3 could induce miR-17/92 expression and leads to repressed protein expression of BMPR2. Therefore, it might involve the pathogenesis of $\mathrm{PH}$ through BMPR2 signaling [42].

miR-20a miR-20a has been reported being targeted explicitly in an in vivo model for $\mathrm{PH}$, and antagomiR-20a could restore functional levels of BMPR2 in pulmonary arteries. It might also be developed to prevent the development of vascular remodeling [49].

\section{Comparison of the different PAH model in previous studies} Some previous studies have used at least two PAH models to confirm their findings, such as PASMCs and animal 
Table 3 The difference of miRNA expression among cell, animal, and human PAH models presented in previous studies

\begin{tabular}{|c|c|c|c|c|c|}
\hline miRNA & Cell model & Animal model & Human PAH model & Consistency & Reference \\
\hline miR-21 & $\begin{array}{l}\text { Up (PAECs) } \\
\text { UP (Spinal fibroblasts) }\end{array}$ & - & $\begin{array}{l}\text { Up } \\
\text { UP (skin tissue) }\end{array}$ & Yes & [22-26] \\
\hline $\operatorname{miR}-29 a-3 p$ & $\begin{array}{l}\text { Down (hypoxia-induced pulmo- } \\
\text { nary adventitial fibroblasts) }\end{array}$ & - & - & N/A & [77] \\
\hline miR-145 & $\begin{array}{l}\text { Up (PASMCs under hypoxic } \\
\text { conditions) }\end{array}$ & Up (hypoxia-induced PAH rats) & $\begin{array}{l}\text { Up (PAH patients under hypoxic } \\
\text { conditions) }\end{array}$ & Yes & [88] \\
\hline miR-124 & - & - & Up (Specimens of PAH patients) & $\mathrm{N} / \mathrm{A}$ & [34] \\
\hline miR-143 & UP (PASMCs) & UP (PAH calf models) & UP (lung tissues of PAH patients) & Yes & [94] \\
\hline miR-29 & - & Up (Bmpr2 mutant mice lungs) & Up (HPAH patients, lung tissue) & Yes & [39] \\
\hline miR-223-3p & $\begin{array}{l}\text { Down (PASMCs of rat with } \\
\text { hypoxia induction) }\end{array}$ & $\begin{array}{l}\text { Down (PAH rats with hypoxia } \\
\text { induction) }\end{array}$ & - & Yes & [98] \\
\hline miR-204 & Down (PAH-PASMCS) & Down (PAH rat model) & - & Yes & [99] \\
\hline miR-130/301 family & Up (PAECs, PASMCs of PAH mice) & $\begin{array}{l}\text { Up (hypoxic PAH mouse } \\
\text { model) }\end{array}$ & Up (PAH patients) & Yes & [44] \\
\hline
\end{tabular}

Abbreviation: Up upregulation of miRNA, PAECs pulmonary artery endothelial cells, Down downregulation of miRNA, CTEPH chronic thromboembolic pulmonary hypertension, HPAH heritable pulmonary arterial hypertension, ECFCs endothelial colony-forming cells

models. However, the consistency of miRNA expression might be different due to various validation systems in the same study. Therefore, to validate the existence of inconsistency, we compared these PAH models of each miRNA used in the same study as listed in Table 3. The results showed high consistency of cell, animal, and human PAH models in and between those previous studies.

\section{Conclusions and perspectives}

This study reviews the miRNAs in PAH and SSc reported in the past decade which might led to exploring a scientific insight into the SSc-PAH and PAH. The increasing knowledge of miRNAs has molded our collective appreciation of the daunting complexity of miRNA-based regulation of gene expression in this disease. Emerging trends in our understanding of the role of miRNAs in the pathogenesis of PAH and SSc might lead to novel diagnostic and therapeutic strategies for the treatment of SSc-PAH or PAH. Increasing literatures focusing on discovering molecular effectors mediating SSc-PAH pathogenesis, including large numbers of miRNA molecules expressed in pulmonary vascular cell types and system-wide regulatory functions in vascular health and disease. However, due to the inherent pleiotropy, overlap, and redundancy of these molecules, it has been challenging to define their integrated effects on overall disease manifestation. This review summarizes our current understanding of the roles of TGF-b/BMPR2 signaling pathway-related miRNAs in PAH and SSc pathology, emphasizing potential biomarkers and/ or therapeutic targets for the disease. In some ways, the complexity of the hierarchical motifs governing their multifunctional and interconnected activities has brought more confusion to the precise, organized structure of miRNA-based mechanisms that drive disease. To overcome those deficiencies, the next phase of research and discovery will necessitate a pipeline of systematic endeavors designed to catalog and identify the hierarchy of activity inherent in these molecular networks. If successful, that next level of insight should further invigorate interest from academia, federal, and industry partners to pursue the collaborative development of more effective miRNA-based diagnostics and therapeutics based on such systems-level understanding of this disease.

\section{Abbreviations}

PAH: Pulmonary arterial hypertension; CTD: Connective tissue disease; SSc: Systemic sclerosis; miRNAs: MicroRNA; IPAH: Idiopathic pulmonary arterial hypertension; SSc-PAH: SSc-associated pulmonary arterial hypertension;

TGF- $\beta$ : Transforming growth factor-beta; BMPR2: Bone morphogenetic protein receptor type II; mPAP: Mean pulmonary artery pressure; RV: Right ventricular; BMP: Bone morphogenetic protein; MCT : Monocrotaline; TGF- $\beta R 1$ : Transforming growth factor-beta receptor type 1; MCT-PH: Monocrotaline-induced pulmonary hypertension; PASMC: Pulmonary artery smooth muscle cell; BMPR1: Bone morphogenetic protein receptor type l; TNF-a: Tumor necrosis factor a; IL-6: Interleukin 6; PH: Pulmonary hypertensive; HPAH: Heritable pulmonary arterial hypertension; PDCD4: Programmed cell death 4; BCl-xL: B cell lymphoma-extra large; DDAH1: Dimethylarginine dimethylaminohydrolases 1; AXIN2: Axis inhibition protein 2; SMAD2: Mothers against decapentaplegic homolog 2; JNK1: c-Jun N-terminal kinase 1; ETS-1: ETS proto-oncogene 1;

COL1A1: Collagen Type I Alpha 1 Chain; SSC-ILD: SSC-systemic sclerosis associated interstitial lung disease; Dnmt1: DNA methyltransferase 1; SOD2: Superoxide dismutase 2; SMURF1: SMAD-specific E3 ubiquitin protein ligase 1; ABCA1: ATP-binding cassette subfamily A member 1ITGB3 integrin subunit beta 3; PTBP1: Polypyrimidine tract-binding protein; PKM2: Pyruvate Kinase M2; NFAT: Nuclear factor of activated T cells; KLF2: Krüppel-like Factor 2; ITGB3: Integrin subunit beta 3; ECM: Extracellular matrix; 16aOHE: 16a-hydroxyestrone; STAT3: Signal transducer and activator of transcription 3; PAECs: Pulmonary artery endothelial cells.

\section{Authors' contributions}

BX: study design; clinical studies; manuscript preparation. GHX: guarantor of integrity of the entire study. YY: manuscript editing. JL: study concepts; manuscript review. All authors read and approved the final manuscript 


\section{Funding \\ None.}

\section{Availability of data and materials}

The datasets used during the current study are available from the corresponding author on reasonable request.

\section{Declarations}

Ethics approval and consent to participate

Not applicable.

\section{Consent for publication}

Not applicable.

\section{Competing interests}

The authors declare that they have no competing interests.

Received: 1 April 2021 Accepted: 7 November 2021

Published online: 25 November 2021

\section{References}

1. Orlandi M, Lepri G, Damiani A, Barsotti S, Di Battista M, Codullo V, et al. One year in review 2020: systemic sclerosis. Clin Exp Rheumatol. 2020;38(Suppl 125(3)):3-17.

2. Campo A, Mathai SC, Le Pavec J, Zaiman AL, Hummers LK, Boyce D, et al. Hemodynamic predictors of survival in scleroderma-related pulmonary arterial hypertension. Am J Respir Crit Care Med. 2010;182:252-60

3. Chung L, Farber HW, Benza R, Miller DP, Parsons L, Hassoun PM, et al Unique predictors of mortality in patients with pulmonary arterial hypertension associated with systemic sclerosis in the REVEAL registry. Chest. 2014;146:1494-504.

4. Condliffe R, Kiely DG, Peacock AJ, Corris PA, Gibbs JS, Vrapi F, et al. Connective tissue disease-associated pulmonary arterial hypertension in the modern treatment era. Am J Respir Crit Care Med. 2009;179:151-7.

5. Kawut SM, Taichman DB, Archer-Chicko CL, Palevsky HI, Kimmel SE. Hemodynamics and survival in patients with pulmonary arterial hypertension related to systemic sclerosis. Chest. 2003;123:344-50.

6. Kolstad KD, Li S, Steen V, Chung L. Long-term outcomes in systemic sclerosis-associated pulmonary arterial hypertension from the Pulmonary Hypertension Assessment and Recognition of Outcomes in Scleroderma Registry (PHAROS). Chest. 2018;154:862-71.

7. Mukerjee D, St George D, Coleiro B, Knight C, Denton CP, Davar J, et al. Prevalence and outcome in systemic sclerosis associated pulmonary arterial hypertension: application of a registry approach. Ann Rheum Dis. 2003;62:1088-93.

8. Rubenfire M, Huffman MD, Krishnan S, Seibold JR, Schiopu E, McLaughlin W. Survival in systemic sclerosis with pulmonary arterial hypertension has not improved in the modern era. Chest. 2013;144:1282-90.

9. Weatherald J, Boucly A, Launay D, Cottin V, Prévot G, Bourlier D, et al Haemodynamics and serial risk assessment in systemic sclerosis associated pulmonary arterial hypertension. Eur Respir J. 2018;52(4):1800678.

10. Chaisson NF, Hassoun PM. Systemic sclerosis-associated pulmonary arterial hypertension. Chest. 2013;144:1346-56.

11. Benza RL, Miller DP, Barst RJ, Badesch DB, Frost AE, McGoon MD. An evaluation of long-term survival from time of diagnosis in pulmonary arterial hypertension from the REVEAL Registry. Chest. 2012;142:448-56.

12. Benza RL, Miller DP, Gomberg-Maitland M, Frantz RP, Foreman AJ, Coffey CS, et al. Predicting survival in pulmonary arterial hypertension: insights from the Registry to Evaluate Early and Long-Term Pulmonary Arterial Hypertension Disease Management (REVEAL). Circulation. 2010;122:164-72.

13. Humbert M, Sitbon O, Chaouat A, Bertocchi M, Habib G, Gressin V, et al. Survival in patients with idiopathic, familial, and anorexigen-associated pulmonary arterial hypertension in the modern management era. Circulation. 2010;122:156-63.
14. Humbert M, Sitbon O, Yaïci A, Montani D, O'Callaghan DS, Jaïs X, et al. Survival in incident and prevalent cohorts of patients with pulmonary arterial hypertension. Eur Respir J. 2010;36:549-55.

15. Launay D, Montani D, Hassoun PM, Cottin V, Le Pavec J, Clerson P, et al. Clinical phenotypes and survival of pre-capillary pulmonary hypertension in systemic sclerosis. PLoS One. 2018;13:e0197112.

16. Sobanski V, Launay D, Hachulla E, Humbert M. Current approaches to the treatment of systemic-sclerosis-associated pulmonary arterial hypertension (SSc-PAH). Curr Rheumatol Rep. 2016;18:10.

17. Bourgeois A, Omura J, Habbout K, Bonnet S, Boucherat O. Pulmonary arterial hypertension: new pathophysiological insights and emerging therapeutic targets. Int J Biochem Cell Biol. 2018;104:9-13.

18. Tielemans B, Delcroix M, Belge C, Quarck R. TGF $\beta$ and BMPRII signaling pathways in the pathogenesis of pulmonary arterial hypertension. Drug Discov Today. 2019;24(3):703-16.

19. Machado RD, Eickelberg O, Elliott CG, Geraci MW, Hanaoka M, Loyd JE, et al. Genetics and genomics of pulmonary arterial hypertension. J Am Coll Cardiol. 2009;54(1 Suppl):S32-42.

20. Coward WR, Saini G, Jenkins G. The pathogenesis of idiopathic pulmonary fibrosis. Ther Adv Respir Dis. 2010;4(6):367-88.

21. Pardali E, Ten Dijke P. TGF $\beta$ signaling and cardiovascular diseases. Int J Biol Sci. 2012;8(2):195-213.

22. Drake KM, Zygmunt D, Mavrakis L, Harbor P, Wang L, Comhair SA, et al. Altered MicroRNA processing in heritable pulmonary arterial hypertension: an important role for Smad-8. Am J Respir Crit Care Med. 2011;184:1400-8.

23. Parikh VN, Jin RC, Rabello S, Gulbahce N, White K, Hale A, et al. MicroRNA-21 integrates pathogenic signaling to control pulmonary hypertension: results of a network bioinformatics approach. Circulation. 2012;125:1520-32.

24. lannone L, Zhao L, Dubois O, Duluc L, Rhodes CJ, Wharton J, et al. miR-21/DDAH1 pathway regulates pulmonary vascular responses to hypoxia. Biochem J. 2014:462:103-12.

25. White K, Dempsie Y, Caruso P, Wallace E, McDonald RA, Stevens H, et al. Endothelial apoptosis in pulmonary hypertension is controlled by a microRNA/programmed cell death 4/caspase-3 axis. Hypertension. 2014;64:185-94.

26. Yang S, Banerjee S, Freitas A, Cui H, Xie N, Abraham E, et al. miR-21 regulates chronic hypoxia-induced pulmonary vascular remodeling. Am J Physiol Lung Cell Mol Physiol. 2012;302:L521-9.

27. Wang W, Liu R, Su Y, Li H, Xie W, Ning B. MicroRNA-21-5p mediates TGF$\beta$-regulated fibrogenic activation of spinal fibroblasts and the formation of fibrotic scars after spinal cord injury. Int J Biol Sci. 2018;14(2):178-88.

28. Izumiya $Y$, Jinnn $M$, Kimura $Y$, Wang $Z$, Onoue $Y$, Hanatani $S$, et al. Expression of Let-7 family microRNAs in skin correlates negatively with severity of pulmonary hypertension in patients with systemic scleroderma. Int J Cardiol Heart Vasc. 2015;8:98-102.

29. Makino K, Jinnin M, Hirano A, Yamane K, Eto M, Kusano T, et al. The downregulation of microRNA let-7a contributes to the excessive expression of type I collagen in systemic and localized scleroderma. J Immunol. 2013;190(8):3905-15.

30. Zhang Y, Xu J. MiR-140-5p regulates hypoxia-mediated human pulmonary artery smooth muscle cell proliferation, apoptosis and differentiation by targeting Dnmt1 and promoting SOD2 expression. Biochem Biophys Res Commun. 2016:473:342-8.

31. Maurer B, Stanczyk J, Jüngel A, Akhmetshina A, Trenkmann M, Brock M, et al. MicroRNA-29, a key regulator of collagen expression in systemic sclerosis. Arthritis Rheum. 2010;62:1733-43.

32. Yue Y, Zhang Z, Zhang L, Chen S, Guo Y, Hong Y. miR-143 and miR-145 promote hypoxia-induced proliferation and migration of pulmonary arterial smooth muscle cells through regulating $A B C A 1$ expression. Cardiovasc Pathol. 2018:37:15-25.

33. Zhu H, Li Y, Qu S, Luo H, Zhou Y, Wang Y, et al. MicroRNA expression abnormalities in limited cutaneous scleroderma and diffuse cutaneous scleroderma. J Clin Immunol. 2012;32:514-22.

34. Zhu TT, Zhang WF, Yin YL, Liu YH, Song P, Xu J, et al. MicroRNA-140-5p targeting tumor necrosis factor-a prevents pulmonary arterial hypertension. J Cell Physiol. 2019;234:9535-50.

35. Zu L, Xue Y, Wang J, Fu Y, Wang X, Xiao G, et al. The feedback loop between miR-124 and TGF- $\beta$ pathway plays a significant role in nonsmall cell lung cancer metastasis. Carcinogenesis. 2016;37:333-43. 
36. Caruso P, Dunmore BJ, Schlosser K, Schoors S, Dos Santos C, PerezIratxeta $\mathrm{C}$, et al. Identification of MicroRNA-124 as a major regulator of enhanced endothelial cell glycolysis in pulmonary arterial hypertension via PTBP1 (Polypyrimidine Tract Binding Protein) and Pyruvate Kinase M2. Circulation. 2017;136:2451-67.

37. Cheng W, Yan K, Xie LY, Chen F, Yu HC, Huang YX, et al. MiR-143-3p controls TGF- $\beta 1$-induced cell proliferation and extracellular matrix production in airway smooth muscle via negative regulation of the nuclear factor of activated T cells 1. Mol Immunol. 2016;78:133-9.

38. Sindi HA, Russomanno G, Satta S, Abdul-Salam VB, Jo KB, Qazi-Chaudhry $B$, et al. Therapeutic potential of KLF2-induced exosomal microRNAs in pulmonary hypertension. Nat Commun. 2020;11:1185.

39. Chen X, Talati M, Fessel JP, Hemnes AR, Gladson S, French J, et al. Estrogen Metabolite 16a-hydroxyestrone exacerbates bone morphogenetic protein receptor type II-associated pulmonary arterial hypertension through microRNA-29-mediated modulation of cellular metabolism. Circulation. 2016;133(1):82-97.

40. Zeng Y, Gao T, Huang W, Yang Y, Qiu R, Hou Y, et al. MicroRNA-455-3p mediates GATA3 tumor suppression in mammary epithelial cells by inhibiting TGF-beta signaling. J Biol Chem. 2019;294(43):15808-25.

41. Liu C, Yang Z, Deng Z, Zhou Y, Gong Q, Zhao R, et al. Upregulated IncRNA ADAMTS9-AS2 suppresses progression of lung cancer through inhibition of miR-223-3p and promotion of TGFBR3. IUBMB Life. 2018;70(6):536-46.

42. Brock M, Trenkmann M, Gay RE, Michel BA, Gay S, Fischler M, et al. Interleukin-6 modulates the expression of the bone morphogenic protein receptor type II through a novel STAT3-microRNA cluster 17/92 pathway. Circ Res. 2009;104:1184-91.

43. Price LC, Wort SJ, Perros F, Dorfmüller P, Huertas A, Montani D, et al. Inflammation in pulmonary arterial hypertension. Chest. 2012;141(1):210-21

44. Bertero T, Lu Y, Annis S, Hale A, Bhat B, Saggar R, et al. Systems-level regulation of microRNA networks by miR-130/301 promotes pulmonary hypertension. J Clin Invest. 2014;124(8):3514-28.

45. Bertero T, Cottrill K, Krauszman A, Lu Y, Annis S, Hale A, et al. The microRNA-130/301 family controls vasoconstriction in pulmonary hypertension. J Biol Chem. 2015;290(4):2069-85.

46. Bertero T, Handen AL, Chan SY. Factors associated with heritable pulmonary arterial hypertension exert convergent actions on the miR130/301-vascular matrix feedback loop. Int J Mol Sci. 2018;19(8):2289.

47. Baptista R, Marques C, Catarino S, Enguita FJ, Costa MC, Matafome P, et al. MicroRNA-424(322) as a new marker of disease progression in pulmonary arterial hypertension and its role in right ventricular hypertrophy by targeting SMURF1. Cardiovasc Res. 2018;114(1):53-64.

48. Chen T, Zhou G, Zhou Q, Tang H, Ibe JC, Cheng H, et al. Loss of microRNA-17 92 in smooth muscle cells attenuates experimental pulmonary hypertension via induction of PDZ and LIM domain 5. Am J Respir Crit Care Med. 2015;191:678-92.

49. Brock M, Samillan VJ, Trenkmann M, Schwarzwald C, Ulrich S, Gay RE, et al. AntagomiR directed against miR-20a restores functional BMPR2 signalling and prevents vascular remodelling in hypoxia-induced pulmonary hypertension. Eur Heart J. 2014;35:3203-11.

50. Kumar R, Mickael C, Kassa B, Gebreab L, Robinson JC, Koyanagi DE, et al. TGF- $\beta$ activation by bone marrow-derived thrombospondin-1 causes Schistosoma- and hypoxia-induced pulmonary hypertension. Nat Commun. 2017;8:15494

51. Gao W, Shao R, Zhang X, Liu D, Liu Y, Fa X. Up-regulation of caveolin-1 by $D J-1$ attenuates rat pulmonary arterial hypertension by inhibiting TGFß/Smad signaling pathway. Exp Cell Res. 2017;361:192-8.

52. Rol N, Kurakula KB, Happé C, Bogaard HJ, Goumans MJ. TGF- $\beta$ and BMPR2 Signaling in PAH: two black sheep in one family. Int J Mol Sci. 2018;19(9):2585.

53. Cunha SI, Magnusson PU, Dejana E, Lampugnani MG. Deregulated TGF- $\beta /$ BMP signaling in vascular malformations. Circ Res. 2017;121(8):981-99.

54. Zaiman AL, Podowski M, Medicherla S, Gordy K, Xu F, Zhen L, et al. Role of the TGF-beta/Alk5 signaling pathway in monocrotalineinduced pulmonary hypertension. Am J Respir Crit Care Med. 2008;177:896-905.

55. Zabini D, Granton E, Hu Y, Miranda MZ, Weichelt U, Breuils Bonnet S, et al. Loss of SMAD3 promotes vascular remodeling in pulmonary arterial hypertension via MRTF disinhibition. Am J Respir Crit Care Med. 2018;197:244-60.

56. Zhang Y, Yuan RX, Bao D. TGF- $\beta 1$ promotes pulmonary arterial hypertension in rats via activating RhoA/ROCK signaling pathway. Eur Rev Med Pharmacol Sci. 2020;24:4988-96.

57. Orriols M, Gomez-Puerto MC, Ten Dijke P. BMP type II receptor as a therapeutic target in pulmonary arterial hypertension. Cell Mol Life Sci. 2017;74:2979-95.

58. Gilbane AJ, Derrett-Smith E, Trinder SL, Good RB, Pearce A, Denton $C P$, et al. Impaired bone morphogenetic protein receptor II signaling in a transforming growth factor- $\beta$-dependent mouse model of pulmonary hypertension and in systemic sclerosis. Am J Respir Crit Care Med. 2015;191:665-77.

59. Gomez-Puerto MC, van Zuijen I, Huang CJ, et al. Autophagy contributes to BMP type 2 receptor degradation and development of pulmonary arterial hypertension. J Pathol. 2019;249(3):356-67.

60. Cogan J, Austin E, Hedges L, Womack B, West J, Loyd J, et al. Role of BMPR2 alternative splicing in heritable pulmonary arterial hypertension penetrance. Circulation. 2012;126:1907-16.

61. Guignabert C, Bailly S, Humbert M. Restoring BMPRII functions in pulmonary arterial hypertension: opportunities, challenges and limitations. Expert Opin Ther Targets. 2017;21:181-90.

62. Austin ED, Cogan JD, West JD, Hedges LK, Hamid R, Dawson EP, et al. Alterations in oestrogen metabolism: implications for higher penetrance of familial pulmonary arterial hypertension in females. Eur Respir J. 2009;34:1093-9.

63. Mair KM, Yang XD, Long L, White K, Wallace E, Ewart MA, et al. Sex affects bone morphogenetic protein type II receptor signaling in pulmonary artery smooth muscle cells. Am J Respir Crit Care Med. 2015;191:693-703.

64. Song Y, Coleman L, Shi J, Beppu H, Sato K, Walsh K, et al. Inflammation, endothelial injury, and persistent pulmonary hypertension in heterozygous BMPR2-mutant mice. Am J Physiol Heart Circ Physiol. 2008;295:H677-90.

65. Burton VJ, Ciuclan LI, Holmes AM, Rodman DM, Walker C, Budd DC. Bone morphogenetic protein receptor II regulates pulmonary artery endothelial cell barrier function. Blood. 2011;117:333-41.

66. Kim CW, Song H, Kumar S, Nam D, Kwon HS, Chang KH, et al. Anti-inflammatory and antiatherogenic role of BMP receptor $\|$ in endothelial cells. Arterioscler Thromb Vasc Biol. 2013:33:1350-9.

67. Soon E, Crosby A, Southwood M, Yang P, Tajsic T, Toshner M, et al. Bone morphogenetic protein receptor type II deficiency and increased inflammatory cytokine production. A gateway to pulmonary arterial hypertension. Am J Respir Crit Care Med. 2015;192:859-72

68. Happé C, Kurakula K, Sun XQ, da Silva Goncalves Bos D, Rol N, Guignabert C, Tu L, Schalij I, Wiesmeijer KC, Tura-Ceide O, Vonk Noordegraaf A, de Man FS, Bogaard HJ, Goumans MJ. The BMP Receptor 2 in Pulmonary Arterial Hypertension: When and Where the Animal Model Matches the Patient. Cells. 2020;9(6):1422.

69. Condorelli G, Latronico MV, Cavarretta E. microRNAs in cardiovascular diseases: current knowledge and the road ahead. J Am Coll Cardiol. 2014;63:2177-87.

70. Thakkar V, Stevens WM, Prior D, Moore OA, Byron J, Liew D, et al. $\mathrm{N}$-terminal pro-brain natriuretic peptide in a novel screening algorithm for pulmonary arterial hypertension in systemic sclerosis: a case-control study. Arthritis Res Ther. 2012;14:R143.

71. van Bon L, Affandi AJ, Broen J, Christmann RB, Marijnissen RJ, Stawski $\mathrm{L}$, et al. Proteome-wide analysis and $\mathrm{CXCL} 4$ as a biomarker in systemic sclerosis. N Engl J Med. 2014;370:433-43.

72. Bergmann C, Distler JH. Epigenetic factors as drivers of fibrosis in systemic sclerosis. Epigenomics. 2017;9:463-77.

73. Tsou PS, Sawalha AH. Unfolding the pathogenesis of scleroderma through genomics and epigenomics. J Autoimmun. 2017:83:73-94

74. van Rooij E, Olson EN. MicroRNAs: powerful new regulators of heart disease and provocative therapeutic targets. J Clin Invest. 2007;117:2369-76.

75. Yuan K, Orcholski M, Tian X, Liao X, de Jesus Perez VA. MicroRNAs: promising therapeutic targets for the treatment of pulmonary arterial hypertension. Expert Opin Ther Targets. 2013;17:557-64. 
76. Wei C, Henderson H, Spradley C, Li L, Kim IK, Kumar S, et al. Circulating miRNAs as potential marker for pulmonary hypertension. PLoS One. 2013;8:e64396.

77. Luo Y, Dong HY, Zhang B, Feng Z, Liu Y, Gao YQ, et al. miR-29a-3p attenuates hypoxic pulmonary hypertension by inhibiting pulmonary adventitial fibroblast activation. Hypertension. 2015;65(2):414-20.

78. Ji H, Li Y, Jiang F, Wang X, Zhang J, Shen J, et al. Inhibition of transforming growth factor beta/SMAD signal by MiR-155 is involved in arsenic trioxide-induced anti-angiogenesis in prostate cancer. Cancer Sci. 2014;105(12):1541-9.

79. Zhu H, Luo H, Li Y, Zhou Y, Jiang Y, Chai J, et al. MicroRNA-21 in scleroderma fibrosis and its function in TGF- $\beta$-regulated fibrosis-related genes expression. J Clin Immunol. 2013:33:1100-9.

80. Zhao F, Wu Y, Yang W, Wu D, Wang C, Zhang F. Inhibition of vascular calcification by microRNA-155-5p is accompanied by the inactivation of TGF-beta1/Smad2/3 signaling pathway. Acta Histochem. 2020;122(4):151551.

81. Bockmeyer CL, Maegel L, Janciauskiene S, Rische J, Lehmann U, Maus UA, et al. Plexiform vasculopathy of severe pulmonary arterial hypertension and microRNA expression. J Heart Lung Transplant. 2012;31(7):764-72.

82. Guo L, Yang Y, Liu J, Wang L, Li J, Wang Y, et al. Differentially expressed plasma microRNAs and the potential regulatory function of Let-7b in chronic thromboembolic pulmonary hypertension. PLoS One. 2014;9(6):e101055.

83. Kawashita Y, Jinnin M, Makino T, Kajihara I, Makino K, Honda N, et al. Circulating miR-29a levels in patients with scleroderma spectrum disorder. J Dermatol Sci. 2011;61:67-9.

84. Zhang SJ, Yun CJ, Liu J, Yao SY, Li Y, Wang M, et al. MicroRNA-29a attenuates angiotensin-II induced-left ventricular remodeling by inhibiting collagen, TGF- $\beta$ and SMAD2/3 expression. J Geriatr Cardiol. 2020;17(2):96-104.

85. Christmann RB, Wooten A, Sampaio-Barros P, Borges CL, Carvalho CR, Kairalla RA, et al. miR-155 in the progression of lung fibrosis in systemic sclerosis. Arthritis Res Ther. 2016:18:155.

86. Rothman AM, Arnold ND, Pickworth JA, Iremonger J, Ciuclan L, Allen RM, et al. MicroRNA-140-5p and SMURF1 regulate pulmonary arterial hypertension. J Clin Invest. 2016;126(7):2495-508.

87. Li F, Shi W, Wan Y, Wang Q, Feng W, Yan X, et al. Prediction of target genes for miR-140-5p in pulmonary arterial hypertension using bioinformatics methods. FEBS Open Bio. 2017;7(12):1880-90.

88. Zhang $X$, Chang A, Li Y, et al. miR-140-5p regulates adipocyte differentiation by targeting transforming growth factor $-\beta$ signaling. Sci Rep. 2015:5:18118

89. Nie X, Chen Y, Tan J, Dai Y, Mao W, Qin G, et al. MicroRNA-221-3p promotes pulmonary artery smooth muscle cells proliferation by targeting AXIN2 during pulmonary arterial hypertension. Vascul Pharmacol. 2019;116:24-35
90. Verjans R, Peters T, Beaumont FJ, van Leeuwen R, van Herwaarden T, Verhesen W, et al. MicroRNA-221/222 Family Counteracts Myocardial Fibrosis in Pressure Overload-Induced Heart Failure. Hypertension. 2018;71(2):280-8

91. Butz H, Rácz K, Hunyady L, Patócs A. Crosstalk between TGF- $\beta$ signaling and the microRNA machinery. Trends Pharmacol Sci. 2012;33:382-93.

92. Kang $K$, Peng $X$, Zhang $X$, Wang $Y$, Zhang L, Gao L, et al. MicroRNA-124 suppresses the transactivation of nuclear factor of activated $T$ cells by targeting multiple genes and inhibits the proliferation of pulmonary artery smooth muscle cells. J Biol Chem. 2013;288:25414-27.

93. Naito Y, Sakamoto N, Oue N, Yashiro M, Sentani K, Yanagihara K, et al. MicroRNA-143 regulates collagen type III expression in stromal fibroblasts of scirrhous type gastric cancer. Cancer Sci. 2014;105:228-35.

94. Deng L, Blanco FJ, Stevens H, Lu R, Caudrillier A, McBride M, et al. MicroRNA-143 activation regulates smooth muscle and endothelial cell crosstalk in pulmonary arterial hypertension. Circ Res. 2015;117:870-83.

95. Ge S, Zhang H, Deng T, Sun W, Ning T, Fan Q, et al. MiR-181a, a new regulator of TGF-beta signaling, can promote cell migration and proliferation in gastric cancer. Invest New Drugs. 2019;37(5):923-34.

96. Bi JG, Zheng JF, Li Q, Bao SY, Yu XF, Xu P, et al. MicroRNA-181a-5p suppresses cell proliferation by targeting Egr1 and inhibiting Egr1/TGF- $\beta /$ Smad pathway in hepatocellular carcinoma. Int J Biochem Cell Biol. 2019;106:107-16.

97. Zhou C, Chen Y, Kang W, Lv H, Fang Z, Yan F, et al. Mir-455-3p-1 represses FGF7 expression to inhibit pulmonary arterial hypertension through inhibiting the RAS/ERK signaling pathway. J Mol Cell Cardiol. 2019;130:23-35.

98. Liu A, Liu Y, Li B, Yang M, Liu Y, Su J. Role of miR-223-3p in pulmonary arterial hypertension via targeting ITGB3 in the ECM pathway. Cell Prolif. 2019;52:e12550

99. Courboulin A, Paulin R, Giguère NJ, Saksouk N, Perreault T, Meloche J, et al. Role for miR-204 in human pulmonary arterial hypertension. J Exp Med. 2011;208(3):535-48.

100. Simonneau G, Gatzoulis MA, Adatia I, Celermajer D, Denton C, Ghofrani A, et al. Updated clinical classification of pulmonary hypertension. J Am Coll Cardiol. 2013;62:D34-41.

101. Girerd B, Weatherald J, Montani D, Humbert M. Heritable pulmonary hypertension: from bench to bedside. Eur Respir Rev. 2017;26(145):170037.

102. Austin ED, Loyd JE. The genetics of pulmonary arterial hypertension Circ Res. 2014;115(1):189-202.

\section{Publisher's Note}

Springer Nature remains neutral with regard to jurisdictional claims in published maps and institutional affiliations.
Ready to submit your research? Choose BMC and benefit from:

- fast, convenient online submission

- thorough peer review by experienced researchers in your field

- rapid publication on acceptance

- support for research data, including large and complex data types

- gold Open Access which fosters wider collaboration and increased citations

- maximum visibility for your research: over $100 \mathrm{M}$ website views per year

At $\mathrm{BMC}$, research is always in progress.

Learn more biomedcentral.com/submissions 